\title{
Microbiological quality of honey from stingless bee, jandaíra (Melipona subnitida), from the semiarid region of Brazil
}

\author{
Carolina de Gouveia Mendes da Escóssia Pinheiro ${ }^{1}$ Maria Rociene Abrantes ${ }^{1}$ \\ Rodrigo Otávio Silveira Silva ${ }^{2^{*}}$ Carlos Augusto Oliveira Junior ${ }^{2}$ \\ Francisco Carlos Faria Lobato ${ }^{1}$ Jean Berg Alves da Silva ${ }^{1}$ (?)
}

${ }^{1}$ Universidade Federal Rural do Semi-Árido (UFERSA), Mossoró, RN, Brasil

${ }^{2}$ Escola de Veterinária. Universidade Federal de Minas Gerais (UFMG), 31.270-901, Belo Horizonte, MG, Brasil. E-mail: rodrigo.otaviosilva@gmail.com. "Corresponding author.

ABSTRACT: The aim of this study was to evaluate the presence of microorganisms in honey produced by the stingless bee (SB) jandaira (Melipona subnitida) from the semiarid region of Brazil. Thirty-five samples were analyzed and all of them were positive for mesophilic bacteria, coliforms at $45^{\circ} \mathrm{C}$, fungi, and yeast. Staphylococcus spp. were identified in $85.7 \%$, while Bacillus spp. were detected in $34.3 \%$ of honey samples. DNAs of Clostridium perfringens and C. botulinum were detected in $40 \%$ and $2.8 \%$ of the samples, respectively. Salmonella spp. and C. difficile were not detected. The present research revealed a great diversity of microorganisms in honey produced by jandaira. Key words: Clostridium botulinum; Clostridium perfringens; stingless bee.

\section{Qualidade microbiológica do mel da abelha sem ferrão jandaíra (Melipona subnitida)} da região semi-árida do Brasil

RESUMO: O objetivo deste trabalho foi avaliar a presença de microrganismos no mel produzido pela abelha sem ferrão jandaíra (Melipona subnitida). Trinta e cinco amostras foram avaliadas e todas foram positivas para bactérias mesofilicas, coliformes a $45^{\circ} \mathrm{C}$, fungos e leveduras. Staphylococcus spp. foi identificado em 85,7\% enquanto Bacillus foi detectado em 34,3\% das amostras de mel. Clostridium perfringens e C. botulinum foram detectados em $40 \%$ e 2,8\% das amostras respectivamente. Salmonella spp. e C. difficile não foram detectados. O presente trabalho revelou uma grande diversidade de microrganismos no mel produzido por jandaíra.

Palavras-chave: Clostridium botulinum; Clostridium perfringens; abelhas sem ferrão.

Jandaíra (Melipona subnitida) is a stingless bee (SB) very common in northeastern Brazil that has been increasingly used for honey production (MAIA et al., 2015). Recently, the Polo de Mel Jandaíra (Honey Pole Jandaíra) was implemented by the Ministério da Integração Nacional (Ministry of National Integration) to organize and encourage the production chain of honey from jandaíra (BRASIL, 2014). The growing demand for this honey in Brazil has encouraged studies on it and it has been already known that honey from $M$. subnitida has some remarkable physicochemical and palynological characteristics (ALMEIDA-MURADIAN et al., 2013). Despite this, reports about the microbiological quality of honey from SB are rare and there is no specific legislation that deals with it, which hinders the characterization and determination of food safety for this product
(MONTE et al., 2013). In this study, we evaluated the microbiological quality of the honey produced by SB jandaíra in the semiarid region of Brazil.

Thirty-five beekeeping farms from 12 cities of the semiarid region of Brazil were visited, with all located in a radius of $177 \mathrm{~km}$ from the geographical loation $4^{\circ} 56^{\prime} 35.9^{\prime \prime} \mathrm{S} 37^{\circ} 18^{\prime} 31.5^{\prime \prime} \mathrm{W}$. In each farm, a 500-mL sample was collected directly from the honeycomb with a sterile syringe, packaged in transparent vials of sterile plastics, and kept protected from light with an average temperature of $25^{\circ} \mathrm{C}$ until microbiological analysis. Detection of mesophilic bacteria, coliforms at $45^{\circ} \mathrm{C}$, Salmonella spp., Staphylococcus spp., fungi, and yeast were performed according to the Brazilian legislation (BRASIL, 2003). For detection of Clostridium perfringens, $C$. difficile, and C. botulinum DNA, each sample was inoculated into Cooked Meat Medium 
(CMM, Difco, USA) broth and Reinforced Clostridial Medium (RCM, Difco, USA) Broth. After incubation at $37^{\circ} \mathrm{C}$ in an anaerobic atmosphere for 48 hours, a $100-\mu \mathrm{L}$ aliquot of the broth culture was subjected to thermal DNA extraction and DNA amplification via PCR to identify $C$. difficile (SILVA et al., 2011), $C$. perfringens (VIEIRA et al., 2008), and C. botulinum (PRÉVOT et al., 2007). In addition, $10 \mu \mathrm{L}$ of the broth was inoculated on Muller-Hinton agar (Difco, USA), which was supplemented with $5 \%$ of sheep blood, and incubated at $37^{\circ} \mathrm{C}$ in an anaerobic atmosphere for 48 hours. Thus, colonies not confirmed as clostridia in previous PCR analyses were subjected to further PCR assessment of 16S rRNA using universal primers (FOX et al., 1995). The amplicons were sequenced and the species were confirmed using BLAST with a similarity of $98 \%$ (MIAN et al., 2009).

Results of the present research are summarized in Table 1. Brazilian legislation categorizes the honey from SB as a product made by $\mathrm{SB}$ or native bees, but no official requirement related to the microbiological quality of the honey from SB is available (BRASIL, 2004; BRASIL, 2017). Beyond that, the Brazilian Ministry of Agriculture, Livestock and Food Supply (MAPA) requires the presentation of scientific literature to ensure the quality and innocuous of the honey from SB (CAMARGO et al., 2017). Considering this, the results of this research will be compared to the microbiological data published in literature for the honey from SB.

All samples were positive for mesophilic bacteria. Most of them (74.3\%) showed counts lower than 25 colony-forming units per gram $(\mathrm{CFU} / \mathrm{g})$, $11.4 \%$ showed between 25 and $2500 \mathrm{CFU} / \mathrm{g}$, and the remaining $14.3 \%$ showed more than $2500 \mathrm{CFU} / \mathrm{g}$. The presence of mesophilic bacteria is related to the deterioration of food. However, some characteristics of honey, such as $\mathrm{pH}$ acidity, low water activity, low protein content, and high sugar, can diminish or stop bacterial activity, contributing to a longer shelf life of the product (EUROPEAN COMMISSION, 2002; MONTE et al., 2013). However, some samples showed a high count of mesophilic bacteria, which some authors attributed to factors associated with the location of the beekeeping farms that can result in contamination. These sources of contamination include soil, water, air, pollen, and nectar (BÁRBARA et al., 2015; OLIVEIRA et al., 2017).

Regarding coliforms at $45^{\circ} \mathrm{C}$, all samples showed results lower than 3.0 most probable number per gram (MPN/g), confirming results of previous studies with different SB honeys, including that from jandaíra bees (SOUZA et al., 2009; MONTE et al., 2013). According to SILVA et al. (2008), values under $3.0 \mathrm{MPN} / \mathrm{g}$ indicated high quality of the honey. However, in a proposal of regulation for the honey from SB, CAMARGO et al. (2017) suggested a threeclass plan for coliforms at $45^{\circ} \mathrm{C}$, with acceptable samples between 0 and $10 \mathrm{MPN} / \mathrm{g}$ and intermediate samples until $100 \mathrm{MPN} / \mathrm{g}$. These values are based on the habit of SB to use a fine mix of propolis and clay to seal the honeycombs (NOGUEIRA-NETO, 1997). Some species even land on feces from vertebrates, which can increase the number of coliforms (SANTOS \& ANTONINI, 2008).

All samples tested were negative for Salmonella spp., in agreement with other studies evaluating the honey from SB (MONTE et al., 2013; PUCCIARELLI et al., 2014). Some studies have shown the antibacterial effect of honey, and the honey from SB in particular, against a wide range of bacteria, including Salmonella (PIMENTEL et al., 2013; NISHIO et al., 2016). As Salmonella is a relevant zoonotic pathogen, CAMARGO et al. (2017) suggested it should be absent in $25 \mathrm{~g}$ of the honey from SB.

Only one sample (2.8\%) showed the presence of Staphylococcus spp. higher than $20 \mathrm{CFU} / \mathrm{g}$, while $97.3 \%$ of the samples had 0 to $20 \mathrm{CFU} / \mathrm{g}$. The low number of staphylococci can be explained by the aseptic collection of honey, since the presence of Staphylococcus spp. in the honey from SB is rare. Equipment and physical honey handling are considered the main sources of contamination by this microorganism (DÜMEN et al., 2013; PUCCIARELLI et al., 2014). In addition, the antimicrobial activities of honey against grampositive bacteria, specifically Staphylococcus spp., were also evaluated. Some studies attributed this effect to hydrogen peroxide, methyl-glyoxal (MGO), hydroxymethylfurfural (HMF), flavonoids, and beedefensins (KWAKMAN et al., 2010; MERCÊS et al., 2013; PIMENTEL et al., 2013; NISHIO et al., 2016).

The average count of fungiand yeast reported in the samples of this study was $9.12 \times 10^{3} \mathrm{CFU} / \mathrm{g}(3.96$ $\log _{10} \mathrm{CFU} / \mathrm{g}$ ). In Brazil, some authors working with the honey from SB considered the maximum threshold to be $100 \mathrm{CFU} / \mathrm{g}\left(2.00 \log _{10} \mathrm{CFU} / \mathrm{g}\right)$ based on national requirements for honey of Apis mellifera (BRASIL, 2000; SOUZA et al., 2009; MONTE et al., 2013). Despite this, CAMARGO et al. (2017) suggested a limit of $1.0 \times 10^{4} \mathrm{CFU} / \mathrm{g}\left(4.00 \log _{10} \mathrm{CFU} / \mathrm{g}\right)$ for the honey from $\mathrm{SB}$, as the elevated humidity of honey associated with the rich fungi microbiota of $\mathrm{SB}$ result in a product with higher counts, as previously described (FERRAZ et al., 2008; MONTE et al., 2013). To date, 
Table 1 - Microorganisms identified in 35 samples of stingless honey from Melipona subnitida (jandaíra bees) collected from the semiarid region of Brazil. MB - Mesophilic bacteria; CFU - Colony-forming units; Col. - Coliforms; MPN - Most probable number; FY - fungi and yeast; CPA - Clostridium perfringens type $\mathrm{A}$; $\mathrm{CBC}-$ Clostridium botulinum type $\mathrm{C}$; $\mathrm{BC}-$ Bacillus cereus; $\mathrm{BL}$ - Bacillus licheniformis; $\mathrm{BC}$-Bacillus cereus.

\begin{tabular}{|c|c|c|c|c|c|c|}
\hline Sample & MB (CFU/g) & Staphylococcus spp. (CFU/g) & FY (CFU/g) & Bacillus spp. & CPA & $\mathrm{CBC}$ \\
\hline 1 & $<25$ & $<20$ & $<15$ & $\mathrm{BC}$ & + & - \\
\hline 2 & $<25$ & $<20$ & $5.4 \times 10^{2}$ & - & - & - \\
\hline 3 & $<25$ & $<20$ & $7.7 \times 10^{2}$ & - & - & - \\
\hline 4 & $2.5 \times 10^{2}$ & $<20$ & $1.0 \times 10^{3}$ & - & - & - \\
\hline 5 & $9.7 \times 10^{2}$ & $<20$ & $1.6 \times 10^{3}$ & - & - & - \\
\hline 6 & $<25$ & $<20$ & $7.1 \times 10^{3}$ & - & - & - \\
\hline 7 & $<25$ & $<20$ & $7.6 \times 10^{2}$ & - & - & - \\
\hline 8 & $<25$ & $<20$ & $<15$ & - & - & - \\
\hline 9 & $<25$ & $<20$ & $<15$ & - & - & - \\
\hline 10 & $>2.5 \times 10^{3}$ & $<20$ & $<15$ & BL & + & - \\
\hline 11 & $>2.5 \times 10^{3}$ & $<20$ & $<15$ & - & - & - \\
\hline 12 & $8.8 \times 10^{2}$ & $<20$ & $1.6 \times 10^{3}$ & BS & + & - \\
\hline 13 & $>2.5 \times 10^{3}$ & $<20$ & $<15$ & - & - & - \\
\hline 14 & $>2.5 \times 10^{3}$ & $<20$ & $<15$ & - & - & - \\
\hline 15 & $<25$ & $<20$ & $<15$ & $\mathrm{BC}$ & + & - \\
\hline 16 & $>2.5 \times 10^{3}$ & $<20$ & $<15$ & - & - & - \\
\hline 17 & $<25$ & $<20$ & $<15$ & - & - & - \\
\hline 18 & $<25$ & $<20$ & $<15$ & $\mathrm{BC}$ & + & - \\
\hline 19 & $<25$ & $<20$ & $<15$ & $\mathrm{BC}$ & + & - \\
\hline 20 & $<25$ & $<20$ & $<15$ & $\mathrm{BC}$ & + & - \\
\hline 21 & $<25$ & $<20$ & $9.3 \times 10^{4}$ & BS & + & - \\
\hline 22 & $<25$ & $<20$ & $<15$ & - & - & - \\
\hline 23 & $3.1 \times 10^{2}$ & $<20$ & $1.3 \times 10^{4}$ & - & - & - \\
\hline 24 & $<25$ & $2.6 \times 10^{3}$ & $2.5 \times 10^{2}$ & - & - & - \\
\hline 25 & $<25$ & $<20$ & $5.0 \times 10^{2}$ & $\mathrm{BC}$ & + & - \\
\hline 26 & $<25$ & 0 & $2.1 \times 10^{3}$ & - & - & - \\
\hline 27 & $<25$ & 0 & $1.0 \times 10^{4}$ & - & - & - \\
\hline 28 & $<25$ & $<20$ & $3.1 \times 10^{3}$ & - & - & - \\
\hline 29 & $<25$ & $<20$ & $1.4 \times 10^{4}$ & BL & - & - \\
\hline 30 & $<25$ & $<20$ & $1.2 \times 10^{4}$ & - & - & - \\
\hline 31 & $<25$ & $<20$ & $1.7 \times 10^{4}$ & - & - & + \\
\hline 32 & $<25$ & 0 & $8.8 \times 10^{4}$ & - & - & - \\
\hline 33 & $<25$ & $<20$ & $5.7 \times 10^{4}$ & - & - & - \\
\hline 34 & $<25$ & 0 & $2.2 \times 10^{2}$ & BL & - & - \\
\hline 35 & $<25$ & 0 & $2.0 \times 10^{2}$ & BL & - & - \\
\hline
\end{tabular}

*All samples were negative for Salmonella spp. and Clostridium difficile. and showed lower than 3.0 most probable number per gram (MPN/g) of coliforms at $45^{\circ} \mathrm{C}$.

there is no description of diseases caused by the fungi and yeast from the honey from SB. Thus, the main problem caused by their presence is the fermentation of honey, which can reduce the shelf life of the product (GRABOWSKY \& KLEIN, 2017).

Bacillus species were reported in $34.3 \%$ of samples, including B. cereus $(17.1 \%)$, B. licheniformis (11.4\%), and B. subtilis (5.7\%). Bacillus are common in SB's honey once these microorganisms have a symbiotic relationship to the bees and a strong antibacterial activity against several pathogens, contributing to the stability of the product (GILLIAM, 1997; TORRES et al., 2015). Although, toxigenic strains of $B$. cereus in honey have been reported, there is no evidence of honey as a vehicle for this pathogen to enter humans (LÓPEZ \& ALIPPI, 2010; SILVA et al., 2017).

$C$. botulinum type $\mathrm{C}$ and $C$. perfringens type A were detected through PCR in $2.8 \%$ and $40.0 \%$ of samples, respectively. PUCCIARELLI et al. (2014) reported that $64 \%$ of the samples tested positive for Clostridium spp. in the honey from SB. Studies investigating the presence of $C$. botulinum in honey from $A$. melifera bees are very common but, to the best of our knowledge, this is the first study to confirm the presence of $C$. botulinum and 
C. perfringens in samples of the honey from SB (NAKANO et al., 1990; NEVAS et al., 2005).

The presence of $C$. perfringens in the honey from SB is relevant once this product is being used for therapeutic purposes to heal wounds as this pathogen is commonly associated with gas gangrene in deep wounds (OLAITAN et al., 2007; MERCÊS et al., 2013). In addition, the detection of $C$. botulinum is of great significance in the present study even though the number of positive samples was lower than those in honey from $A$. mellifera bees (NAKANO et al., 1990; RAGAZANI et al., 2008). C. botulinum is responsible for infant botulism, which is commonly associated with honey consumption (CAGAN et al., 2010; DABRITZ et al., 2014). Interestingly, most cases of botulism are caused by $C$. botulinum type A and B. However, one case of infant botulism was caused by $C$. botulinum type $\mathrm{C}$, the same type detected in the present study that had already been described previously (OGUMA et al., 1990; BROWN \& DESAI, 2013). Thus, the detection of $C$. botulinum type $\mathrm{C}$ suggested that honey produced by jandaíra bees might pose a risk to infants under one year of age and consumers should be clearly warned about this risk on the product label (EUROPEAN COMMISSION, 2002; BRASIL, 2017).

The present study revealed a broader microbiological profile of the honey from SB compared to that of the honey from $A$. mellifera, which draws attention to the need for a specific legislation for this product and the adoption of measures to reduce the number of contaminants (SILVA et al., 2008). Good beekeeping practices associated with conservation techniques are important in guaranteeing a product of high quality. However, more studies are necessary to evaluate the effects of such practices on the physical and chemical characteristics of the honey from SB, specifically jandaíra honey (SOUZA et al., 2009; MOURA et al., 2014).

\section{ACKNOWLEDGMENTS}

This research was supported by funds from Fundação de Amparo à Pesquisa do Estado de Minas Gerais (FAPEMIG), Coordenação de Aperfeiçoamento de Pessoal de Nível Superior (CAPES), Conselho Nacional de Desenvolvimento Científico e Tecnológico $(\mathrm{CNPq})$ and Pró-Reitoria de Pesquisa Universidade Federal de Minas Gerais (PRPq-UFMG).

\section{DECLARATION OF CONFLICTING OF INTERESTS}

The authors declare no conflict of interest. The founding sponsors had no role in the design of the study; in the collection, analyses, or interpretation of data; in the writing of the manuscript, and in the decision to publish the results.

\section{REFERENCES}

ALMEIDA-MURADIAN, L.B. et al. Comparative study of the physicochemical and palynological characteristics of honey from Melipona subnitida and Apis mellifera. International Journal of Food Science and Technology, v.48, p.1698-1706, 2013. Available from: < https://onlinelibrary.wiley.com/doi/full/10.1111/ ijfs.12140>. Accessed: Jan. 30, 2018. doi: 10.1111/ijfs.12140.

DABRITZ, H. A.; et al. Molecular epidemiology of infant botulism in California and elsewhere, 1976-2010. The Journal of Infectious Diseases, v.210, p.1711-22, 2014. Available from: $<$ https://www.ncbi.nlm.nih.gov/pubmed/24924163>. Accessed: Jan. 30, 2018. doi: 10.1093/infdis/jiu331.

BÁRBARA, M.S. et al. Microbiological assessment, nutritional characterization and phenolic compounds of bee pollen from Mellipona mandacaia Smith, 1983. Molecules, v.9, n.7, p.12525-12544, 2015. Available from: <http://www.mdpi.com/1420-3049/20/7/12525>. Accessed: Dez. 30, 2017. doi: 10.3390/molecules200712525.

BRASIL. Instrução Normativa n. 11, de 20 de outubro de 2000. Aprova o Regulamento Técnico de Identidade e Qualidade do Mel. Diário Oficial da União, Poder Executivo, Brasília, DF. Out. 23, 2000. Seção 1, p.23.

BRASIL. Instrução Normativa n. 62, de 26 de agosto de 2003. Oficializa os métodos analíticos oficiais para análises microbiológicas para controle de produtos de origem animal e água. Diário Oficial da União, Poder Executivo, Brasília, DF. Set. 18,2003 . Seção 1, p.14.

BRASIL. Resolução CONAMA n. 346, de 16 de agosto de 2004. Disciplina a utilização de abelhas silvestres nativas, bem como a implantação de meliponários. Diário Oficial da União, Poder Executivo, Brasília, DF. Ago. 14, 2004. Seção 1, p. 70.

BRASIL. Portaria n. 162, de 24 de abril de 2014. Estabelece as Rotas de Integração Nacional como estratégia de Inclusão Produtiva e Desenvolvimento Regional do Ministério de Integração Nacional. Diário Oficial da União, Poder Executivo, Brasília DF. Abr. 28, 2014. Seção 1, p. 30.

BRASIL. Decreto n.9.013, de 29 de março de 2017. Regulamentação da Lei n. 1.283, de 18 de dezembro de 1950 e a Lei n. 7.889, de 23 de novembro de 1989, que dispõem sobre a inspeção industrial e sanitária de produtos de origem animal. Diário Oficial da União, Poder Executivo, Brasília, DF. Mar. 30, 2017. Seção 1, p.3.

BROWN, N.; DESAI, S. Infantile botulism: a case report and review. The Journal of Emergence Medicine, v.45, n.6, p.842845, 2013. Available from: <https://www.sciencedirect.com/ science/article/pii/S0736467913005131?via\%3Dihub>. Accessed: Dez. 30, 2017. doi: 10.1016/j.jemermed.2013.05.017.

CAGAN, E. Infant botulism. The Eurasian Journal of Medicine, v.42, p.92-94, 2010. Available from: <https://www.ncbi.nlm.nih. gov/pmc/articles/PMC4261338/pdf/eajm-42-2-92.pdf>. Accessed: Dez. 26, 2017

CAMARGO, R.C.R et al. Stingless bee honey: technical regulation proposal. Brazilian Journal of Food Technology, v.20, e2016157, 2017. Available from: <http://www.scielo.br/scielo. php? script $=$ sci_arttext\&pid $=$ S 1981-67232017000100900\&ln $\mathrm{g}=\mathrm{pt} \& \operatorname{tlng}=\mathrm{pt}>$. Accessed: Dez. 26, 2017. doi: 10.1590/19816723.15716 
DÜMEN, E. et al. Microbiological and parasitological quality of honey produced in Ístanbul. Turkish Journal of Veterinary and Animal Sciences, v.37, p.602-607, 2013. Available from: $<\mathrm{http}: / /$ dergipark.gov.tr/download/article-file/131957>. Accessed: Dez. 04, 2017. doi: 10.3906/vet-1301-46.

EUROPEAN COMMISSION. Opinion of the scientific committee on veterinary measures relating to public health on honey and microbiological hazards. Health \& Consumer Protection Directorate-General, 19 Jun. 2002. Available from: $<$ https://ec.europa.eu/food/sites/food/files/safety/docs/sci-com scv_out53_en.pdf $>$. Accessed: Dez. 04, 2017.

FERRAZ, R.E. et al. Microbiota fúngica de Melipona subnitida Ducke (Hymenoptera: Apidae). Neotropical Entomology, v.37, n.3, p.345-346, 2008. Available from: <http://www.scielo.br/ scielo.php?script=sci_arttext\&pid=S1519-566X2008000300017> Accessed: Dez. 01, 2017. doi: 10.1590/S1519-566X2008000300017.

FOX, J.G. et al. Helicobacter bilis sp. nov.: a novel helicobacter species isolated from bile, livers, and intestines of aged, inbred mice. Journal of Clinical Microbiology, v.33, n.2, p.445-454, 1995. Available from: <http://jcm.asm.org/content/33/2/445.full. pdf>. Accessed: Dez. 01, 2017.

GILLIAM M. Identification and roles of non-pathogenic microflora associated with honey bees. Fems Microbiology Letters, v.155, n.1, p.1-10, 1997. Available from: <http://onlinelibrary.wiley.com/ doi/10.1111/j.1574-6968.1997.tb12678.x/epdf>. doi: 10.1111/ j.1574-6968.1997.tb12678.x/epdf.

GRABOWSKY, N.T.; KLEIN, G. Microbiology and foodborne pathogens in honey. Critical Reviews in Food Science and Nutrition, v.57, n.9, p.1852-1862, 2017. Available from: <http:// www.tandfonline.com/doi/abs/10.1080/10408398.2015.1029041?j ournalCode=bfsn20 $>$. doi: 10.1080/10408398.2015.1029041.

KWAKMAN, P.H.S. et al. How honey kills bacteria. The FASEB Journal, v.24, p.2577-2582, 2010. Available from: <https://www. fasebj.org/doi/pdf/10.1096/fj.09-150789>. Accessed: Jan. 11, 2018. doi: 10.1096/fj.09-150789.

LÓPEZ A.C.; ALIPPI A.M. Enterotoxigenic gene profiles of Bacillus cereus and Bacillus megaterium isolates recovered from honey. Revista Argentina Microbiología, v.42, n.3, p.216-25, 2010. Available from: <http://www.scielo.org.ar/pdf/ram/v42n3/ v42n3a14.pdf>. Accessed: Nov. 20, 2017.

MAIA, U.M. et al. Meliponicultura no Rio Grande do Norte Revista Brasileira de Medicina Veterinária, v.37, n.4, p.327333, 2015. Available from: <http://www.rbmv.org/index.php/ BJVM/article/download/425/316>. Accessed: Dez. 24, 2017.

MERCÊS, M.D. et al. Antimicrobial activity of honey from five species of Brazilian stingless bees. Ciência Rural, v.43, n.4, p.672-675, 2013. Available from: <http://www.scielo. br/scielo.php?pid $=$ S0103-84782013000400017\&script $=$ sci abstract\&tlng $=\mathrm{pt}>$. Accessed: Jan. 24, 2018.

MIAN, G.F. et al. Aspects of the natural history and virulence of $S$ agalactiae infection in Nile tilapia. Veterinary Microbiology, v.136, n.1-2, p.180-183, 2009. Available from: <https://www.sciencedirect. com/science/article/pii/S0378113508004926?via\%3Dihub>. Accessed: Dez. 20, 2017.

MONTE, A.M. et al. Quality of honey from stingless bees native of Piaui, Brazil. Revista Brasileira de Medicina Veterinária, v.35, n.1, p.48-54, 2013. Available from: <http://www.rbmv.com. br/pdf_artigos/02-07-2013_11-21RBMV\%20009.pdf>. Accessed: Dez. 20, 2017.

MOURA, J.Z. et al. Qualidade do mel de Apis mellifera L. relacionadas às boas práticas apícolas. Revista Brasileira de Saúde e Produção Animal, v.15, n.3, p.731-739, 2014. Available from: <http://www.scielo.br/scielo.php?pid=S1519$99402014000300021 \&$ script $=$ sci abstract\&tlng=pt>. Accessed: Dez. 23, 2017. doi: 10.1590/S1519-99402014000300021.

NAKANO, H. et al. Incidence of Clostridium botulinum in honey of various origins. Japanese Journal of Medical Science and Biology, v.43, p.183-185, 1990. Available from: <https://www. jstage.jst.go.jp/article/yoken1952/43/5/43_5_183/_article>. Accessed: Dez. 20, 2017. doi: 10.7883/yoken1952.43.183.

NEVAS, M. et al. Prevalence and diversity of Clostridium botulinum types A, B, E and F in honey produced in the Nordic countries. International Journal of Food Microbiology, v.105, n.2, p.145-151, 2005. Available from: <https://www.sciencedirect. com/science/article/pii/S016816050500320X>. Accessed: Dez. 21, 2017. doi: 10.1016/j.ijfoodmicro.2005.04.007.

NISHIO, E.K. et al. Antibacterial synergic effect of honey from two stingless bees: Scaptotrigona bipunctata Lepeletier, 1836, and S. postica Latreille, 1807. Scientific Reports, v.6, p.21641, 2016. Available from: <https://www.ncbi.nlm.nih.gov/pmc/articles/ PMC4751499/pdf/srep21641.pdf $>$. Accessed: Dez. 26, 2017. doi: $10.1038 /$ srep21641.

NOGUEIRA-NETO, P. Vida e criação de abelhas indígenas sem ferrão. São Paulo: Editora Nogueirapis, 1997. 445p.

OGUMA, K. et al. Infant botulism due Clostridium botulinum type C toxin. The Lancet, v.336, n.8728, 1449-1450, 1990. Available from: <https://www.sciencedirect.com/science/article/ pii/014067369093157K?_rdoc=1\&_fmt=high\&_origin=gateway\&_ docanchor $=\& \mathrm{md} 5=\mathrm{b} 8429449 \mathrm{ccfc} 9 \mathrm{c} 30159 \mathrm{a} 5 \mathrm{f} 9 \mathrm{aea} 92 \mathrm{ffb}>$. Accessed: Dez. 26, 2017. doi: 10.1016/0140-6736(90)93157-K.

OLAITAN, P.B. et al. Honey: a reservoir for microorganisms and an inhibitory agent for microbes. African Health Sciences, v.7, n.3, p.159-165, 2007. Available from: <https://www.ajol.info/ index.php/ahs/article/view/7009/58269>. Accessed: Dez. 23, 2017.

OLIVEIRA, R.G. et al. Screening for quality indicators and phenolic compounds of biotechnological interest in honey samples from six species of stingless bees (Hymenoptera: Apidae). Food Science and Technology, v.37, n.4, p.552-557, 2017. Available from: <http://www.scielo.br/scielo.php?pid=S010120612017005005106\&script=sci abstract $>$. Accessed: Dez. 18, 2017. doi: $10.1590 / 1678-457 \times .25716$.

PIMENTEL, R.B.Q. et al. Antimicrobial activity and rutin identification of honey produced by the stingless bee Melipona compressipes manaosensis and commercial honey. BMC Complementary and Alternative Medicine, v.13, p.151, 2013. Available from: <https:// www.ncbi.nlm.nih.gov/pmc/articles/PMC3702439/pdf/1472-6882-13151.pdf $>$. Accessed: Dez. 23, 2017. doi: 10.1186/1472-6882-13-151.

PRÉVOT, V. et al. Optimization of polymerase chain reaction for detection of Clostridium botulinum type $\mathrm{C}$ and $\mathrm{D}$ in bovine samples. Zoonosis Public Health, v.54, n.8, p.320-327, 2007. Available from: <http://onlinelibrary.wiley.com/doi/10.1111/ j.1863-2378.2007.01070.x/full>. Accessed: Dez. 18, 2017.

Ciência Rural, v.48, n.9, 2018. 
PUCCIARELLI, A.B. et al. Microbiological and physicochemical analysis of yateí (Tetragonisca angustula) honey for assessing quality standards and commercialization. Revista Argentina de Microbiología, v.46, n.4, p.325-332, 2014. Available from:<https:// www.sciencedirect.com/science/article/pii/S0325754114700914>. Accessed: Dez. 18, 2017. doi: 10.1016/S0325-7541(14)70091-4.

RAGAZANI, A.V.F. et al. Esporos de Clostridium botulinum em mel comercializado no estado de São Paulo e em outros estados brasileiros. Ciência Rural, v.38, n.2, p.396-399, 2008. Available from: <http:// www.scielo.br/pdf/cr/v38n2/a16v38n2.pdf>. Accessed: Dez. 18, 2017. doi: 10.1590/S0103-84782008000200016.

SANTOS, G.M.; ANTONINI, Y. The traditional knowledge on stingless bees (Apidae: Meliponina) used by the EnaweneNawe tribe in western Brazil. Journal of Ethnobiology and Ethnomedicine, v.4, p.19, 2008. Available from: <https:// ethnobiomed.biomedcentral.com/track/pdf/10.1186/1746-4269-419>. Accessed: Dez. 20, 2017. doi: 10.1186/1746-4269-4-19.

SILVA, M.B.L. et al. Qualidade microbiológica de méis produzidos por pequenos apicultores e de méis de entrepostos registrados no serviço de inspeção federal no estado de Minas Gerais. Alimentos e Nutrição, v.19, n.4, p.417-420, 2008.

SILVA, R.O.S. et al. Detection of enterotoxin A and cytotoxin B, and isolation of Clostridium difficile in piglets in Minas Gerais, Brazil. Ciência
Rural, v.41, n.8, p.1130-35, 2011. Available from: <http://www.scielo. br/scielo.php?script=sci arttext\&pid=S0103-84782011000800021>. Accessed: Dez. 17, 2017. doi: 10.1590/S0103-84782011005000100.

SILVA, M.S. et al. Microorganisms in honey. In: Toledo, V.A.A. Honey Analysis. Rijeka: In Tech, 2017. Cap.11, p.233-258.

SOUZA, B.A. et al. Avaliação microbiológica de amostras de mel de trigoníneos (Apidae: Trigonini) do estado da Bahia. Ciência e Tecnologia de Alimentos, v.29, n.4, p.798-802, 2009. Available from: $\quad<$ http://www.scielo.br/scielo.php?script=sci arttext\&pid $=$ S0101-20612009000400015>. Accessed: Dez. 22, 2017. doi: 10.1590/S0101-20612009000400015.

TORRES, M.J. et al. Bacillus subtilis subsp. subtilis CBMDC3F with antimicrobial activity against gram-positive foodborne pathogenic bacteria: UV-MALDI-TOF MS analysis of its bioactive compounds. World Journal of Microbiology and Biotechnology, v.31, n.6, p.929-940, 2015. Available from: <https://link.springer. com/article/10.1007\%2Fs11274-015-1847-9>. Accessed: Dez. 27, 2017. doi: 10.1007/s11274-015-1847-9.

VIEIRA, A.A.S. et al. Genotipagem de Clostridium perfringens isolados de leitões diarreicos. Arquivos do Instituto Biológico, v.75, n.4, p.513-516. 2008. Available from: <https://www.researchgate.net/ publication/258021724_Genotipagem_de_Clostridium_perfringens_ isolados_de_leitoes_diarreicos>.Accessed: Dez. 10, 2017. 